\title{
The Image at the Service of the Text: Figured Masorah in the Biblical Hebrew Manuscript BH Mss1*
}

Elvira Martín Contreras**

ILC-CSIC

LA IMAGEN AL SERVICIO DEL TEXTO: MASORA ORNAMENTAL EN EL MANUSCRITO BÍBLICO HEBREO BH Mss1.- Las noticias masoréticas escritas en formas geométricas o figurativas que aparecen junto al texto bíblico han sido poco estudiadas hasta la fecha. Los escasos estudios existentes se suelen centrar en la forma, sin tener en cuenta el contenido. El manuscrito bíblico BH Mss1 (M1) contiene un gran número de noticias masoréticas en forma figurativa que, si bien ya habían sido mencionadas, sus diseños no han sido descritos ni estudiados en relación con su contenido. El presente trabajo se centra en las noticias de Masora figurativa, su localización, forma y contenido. El análisis conjunto de la forma y el contenido de las noticias permite concluir que la razón principal para escribir la Masora en forma figurativa en M1 es práctica.

PALABRAS ClAVE: Biblia hebrea; Sefarad; Edad Media; micrografía; masora ornamental.

The Masoretic notes that appear alongside the biblical text written in geometric or figured shapes are little studied to date. The few existing studies usually focus on the form without paying attention to the content. The biblical Hebrew manuscript BH Mss1 (M1) has a huge number of Masoretic notes in figured patterns and while the existence of figured Masorah has been addressed, their designs have not been described and studied in relation to their content. This paper focuses on the figured Masorah notes, their location, shape and content. From a joint analysis of the form and content it is possible to conclude

"Formerly shelf-marked Ms 118-Z-42. This article is the result of a research carried out under the auspices of the project "The Role of the Rabbinic Literature in the Textual Transmission of the Hebrew Bible II" (Ref: FFI2011-22888), part of the R\&D Programme of the Spanish Ministry of Science and Innovation (MICINN). Most of the issues dealt with in that paper were presented at the tenth congress of the European Association for Jewish Studies (EAJS) that took place in Paris on July 22nd 2014.

***elvira.martin@cchs.csic.es 
that the main purpose behind writing the Masorah in figured patterns in M1 is a practical one: to record all the information in the available space.

KeYwords: Hebrew Bible; Sefarad; Middle Ages; Micrography; Ornamental Masorah.

\section{INTRODUCTION}

The Masoretic notes that appear along with the biblical text written in geometric or figured shapes have scarcely been studied to date. The few existing studies come from the field of Jewish art. ${ }^{1}$ These works, however, do not usually pay attention to the content, but focus on the form. Considering micrography as a scribal art that uses the text to form the image ${ }^{2}$ in which the text loses its function of being read, ${ }^{3}$ they do not concern themselves with the information contained in the text. One exception, to the best of my knowledge is the work by Leila Avrin on the earliest dated biblical codex, the Cairo Codex of the Prophets, attributed to Moshe ben Asher. ${ }^{4}$ Avrin was the first to concentrate on both form and content and to read the Masorah in figured patterns in its entirety.

Moreover, these studies do not agree about the terminology used to name the Masoretic notes written in figured patterns. Different terms are used, such as: "figured Masorah;" "Masorah figurata;", "micrographic

${ }^{1}$ For the state of the art, cf. D. R. HALPERIN, Illuminating in Micrography: The Catalan Micrography Mahzor-MS Heb $8^{\circ} 6527$ in the National Library of Israel (=The Medieval and Early Modern Iberian World, 51; Leiden-Boston: Brill, 2013) pp. 16-18.

${ }^{2}$ HalPerin, Illuminating in Micrography, p. 4.

${ }^{3}$ C. SiRAT, Hebrew Manuscripts of the Middle Ages (Cambridge: Cambridge University Press, 2002) p. 155.

${ }^{4}$ L. Avrin, The Illuminations in the Moshe Ben Asher Codex of 895 C. E. (2 vols; Ph.D. Dissertation; The University of Michigan, 1974).

${ }^{5}$ Avrin, The Illuminations in the Moshe Ben Asher Codex, pp. 157-161. More recently, Halperin has discussed the need to read "the micrography decoration" in its entirety, cf. HALPERIN, Illuminating in Micrography, p. 20.

${ }^{6}$ Avrin, The Illuminations in the Moshe Ben Asher Codex, pp. 157-158.

${ }^{7}$ J. Guttman, "Masorah Figurata: The Origins and Development of a Jewish Art Form," in Estudios Masoréticos (V Congreso de la IOMS). Dedicados a Harry M. Orlinsky, ed. E. Fernández TeJERo (Madrid: CSIC, 1983) pp. 49-62. 
masorah with geometric patterns," "masorah decorations in micrography" and "masorah decorations in geometric patterns;", "marginal micrography decorations;" "decorated masorah;" Masora Ornamentale, masora magna décorative and décoration massoretique; ${ }^{11}$ etc.

In the field of Masoretic Studies, the treatment of this subject has been limited to an acknowledgement of the existence of the Masorah in figured patterns - called "ornamental masorah" and considered of little worth for the study of the Masorah $-{ }^{12}$ and to reading their content when they are part of a manuscript in which the entire Masorah is being edited and studied. $^{13}$ This is true for the edition and publication of the Masorot in manuscript BH Mss1 (M1) done by the Hebrew Bible team at the Spanish Council for Scientific Research (CSIC), which I am a member of. ${ }^{14}$

\footnotetext{
${ }^{8}$ K. Kogman-Appel, Jewish Book Art between Islam and Christianity. The Decoration of Hebrew Bibles in Medieval Spain (=The Medieval and Early Modern Iberian World, 19; Leiden-Boston: Brill, 2004) pp. 44, 46 and 47.
}

${ }^{9}$ HaLPERIN, Illuminating in Micrography, pp. 7, 19 and 20.

${ }^{10}$ D. R. HALPERIN, "Decorated Masorah on the Openings between Quires in Masoretic Bible Manuscripts," JJS 65:2 (2014) pp. 323-348.

${ }^{11}$ T. Metzger, "La Masora Ornamentale et la Décor Calligraphique dans les manuscrits hébreux espagnols au moyen age" in La Paléographie Hébraïque Médievale. Actes du Colloque International sur la Paléographie Hébraïque Médiévale, Paris, 11-13 septembre 1972, eds. J. GLÉNISSON and C. SiRAT (Paris: CNRS, 1974) pp. 87-116.

12 The Masorah of the later manuscripts $\left(12^{\text {th }}-13^{\text {th }}\right.$ century $)$ is considered inaccurate, with a mainly decorative function. However, these assertions are not based on an in-depth study of the subject; cf. A. Dotan, "Masora," EJ 13 (2007) pp. 603-656: 620; I. YeIvin, Introduction to the Tiberian Masorah. Translated by E. J. Revell (Missoula, MT: Scholars Press, 1980) p. 125.

${ }^{13}$ One exception is the edition and study of the "figurative masorah" from ms. Vat. Ebr. 14 being done by Élodie Attia from a 'text-images relationship' perspective. For a presentation of the project cf. E. AттіA, "Editing Medieval Ashkenazi Masorah and Masorah Figurata: Observations on the Functions of the Micrography in Hebrew Manuscripts," Sefarad 75:1 (2015) pp. 7-33.

${ }^{14}$ E. Fernández Tejero, Las masoras del libro de Génesis. Códice M1 de la Universidad Complutense de Madrid (Madrid: CSIC, 2004); M. ${ }^{a}$ T. Ortega Monasterio, Las masoras del libro de Éxodo. Códice M1 de la Universidad Complutense de Madrid (Madrid: CSIC, 2002); M. ${ }^{a}$ J. AzCÁrRaga Servert, Las masoras del libro de Levítico. Códice M1 de la Universidad Complutense de Madrid (Madrid: CSIC, 2004); M. ${ }^{a}$ J. Azcárraga Servert, Las masoras del libro de Números. Códice M1 de la Universidad Complutense de Madrid (Madrid: CSIC, 2001); G. SEIJAS DE LOS Ríos, Las masoras del 
This high quality manuscript ${ }^{15}$ is a Masoretic Bible that comprises the entire Hebrew Bible except for the folios which contain Ex 9:33b-34:7b (340 unpaged folios), with the notes that form the Masorah Parva (MP) and Masorah Magna (MM). ${ }^{16}$ In addition, a number of lengthy Masoretic rubrics are given as appendices at the end of the main divisions (Pentateuch, Former Prophets, Latter Prophets and Writings). ${ }^{17}$ According to the note of purchase found on fol. 334v, it was bought by R. Yishaq and R. Abraham, both doctors, in Toledo in 1280.

The manuscript has a huge number of Masoretic notes in figured patterns. The existence of figured Masorah has been already mentioned ${ }^{18}$ and those found in the Pentateuch and Joshua read and edited $;{ }^{19}$ however, their designs have not been described and studied in relation to their content.

This paper focuses on the figured Masorah notes, their location, shape and content.

Given the nature of this study, which pays attention to both the form and the text, it is going to follow, to the extent possible, the terminology

libro de Deuteronomio. Códice M1 de la Universidad Complutense de Madrid (Madrid: CSIC, 2002); E. Fernández Tejero, Las masoras del libro de Josué. Códice M1 de la Universidad Complutense de Madrid (Madrid: CSIC, 2009).

${ }^{15} \mathrm{Cf}$. Ch. D. Ginsburg, Introduction to the Massoretico-Critical Edition of the Hebrew Bible (New York: Ktav Publishing House Inc., 1966) pp. 771 and 775-776.

${ }^{16}$ For the description and codicological study, cf. E. FernándeZ TeJero, La tradición textual española de la Biblia hebrea: el manuscrito 118-Z-42 (M1) de la Biblioteca de la Universidad Complutense de Madrid (Madrid: CSIC, 1976); F. J. DEL BARCO DEL BARCO, Catálogo de manuscritos hebreos de la Comunidad de Madrid. Vol. I (Madrid: CSIC, 2003) pp. 109-112. The manuscript can be consulted online at: http://dioscorides.ucm.es/ proyecto_digitalizacion/index.php?doc $=5309439296 \& \mathrm{y}=2011 \& \mathrm{p}=1$.

${ }^{17}$ The appendices have been edited and studied in E. Martín-Contreras, Apéndices Masoréticos. Códice M1 de la Universidad Complutense de Madrid (Textos y Estudios "Cardenal Cisneros," 72; Madrid: CSIC, 2004), and "M1's Massoretic Appendices: A New Description," Journal of Northwest Semitic Languages 32:1 (2006) pp. 65-81.

${ }^{18}$ For instance, Metzger, "La Masora Ornamentale,” p. 99; Kogman-Appel, Jewish Book Art, p. 60; HalPerin, Illuminating in Micrography, pp. 83-84; M. ${ }^{a}$ T. Ortega Monasterio, "Historia y formación de las colecciones de manuscritos hebreos en España," in Biblias de Sefarad, eds. E. Alfonso, J. del Barco, M. ${ }^{a}$ T. Ortega Monasterio and A. PRATs (Madrid: BNE, 2012) pp. 149-175.

${ }^{19} \mathrm{Cf}$. footnote 15 . 
and approach used by Avrin in her description of the masorah in figured patterns from the Cairo Codex, combining it with the methodology and terminology used in the field of Masoretic Studies. ${ }^{20}$

\section{Masoretic nOtes in FIGURED PATTERns: PlaCE AND SHAPE}

These notes have been located in the MP, the MM and the sekum, - a short summary with general information that was usually placed at the end of each biblical book. ${ }^{21}$

\subsection{Masorah Parva}

These Masoretic notes are mainly written in straight lines in the right or left margin of the line of the biblical text where the word - normally marked with a circellus - to which they refer is placed. To a lesser extent, the notes are written in figured patterns (especially in the Pentateuch and the Writings) in the inter-column spaces and occasionally in the outer margins. At times, these notes begin at a level different to that of the word in the biblical text to which they refer. In seven cases (fols. 7r, 22r, 23r, 25r, 60v, 62r, 124r), the MP notes are placed around a decorated seder mark and once (fol. 80r) around a decorated parashah mark.

The variety of patterns used in this Masorah is wide, up to twenty-nine different designs, some used just once (i.e. fols. 7v, 106v, 136r, 167r, $205 \mathrm{r}, 213 \mathrm{v})$. The most common designs are one and two vertical parallel lines and the triangle and its variants (double-lined triangle, triangle with a line in the middle, etc.).

It is worth noting that in many of these notes, the figured pattern is combined with the usual form, i.e. writing in horizontal strokes. The in-

${ }^{20}$ E. Martín-Contreras and G. Seijas de los Ríos-Zarzosa, Masora. La transmisión de la tradición de la Biblia Hebrea (Estella: Editorial Verbo Divino, 2010).

${ }^{21}$ Cf. E. DE Faria Franciso, Manual da Bíblia Hebraica. Introduçao ao Texto Massorético ( $3^{\mathrm{a}}$ ed.; Sau Paulo: Vida Nova, 2008) pp. 169-172. This information is called Masora finalis in works from the field of art studies; however, as the Masoretic material arranged by Jacob ben Hayyim at the end of the second rabbinic Bible is called Masorah finalis, it is better to avoid this term. 
formation contained in the note usually begins without any decoration and later continues in simple geometric shapes, which generally consist of a vertical line (fols. 7r, 16r, 19v, 27v, 66v, 69v, 79v, 164r, 206v, etc.).

Although MP notes written in figured patterns are usually on one word, there are some exceptions where there are two or more notes - each one dealing with one word - using the same design. These notes can be written in the same direction, separated from each other by the sequence of: two dots-circle-two dots (fol. 260r), or appearing opposite directions (fols. 124r, 264v and 305r).

\subsection{Masorah Magna}

The MM is usually divided - taking into the account the place where the notes appear - into upper MM (at the top margin) and lower MM (at the lower margin). The Masoretic notes written in figured pattern are found in both places.

\subsubsection{The upper MM}

The notes placed in this Masorah are mainly written in three straight lines ${ }^{22}$ combined with figured patterns - mainly geometrical - usually placed under the last line and on top of the two inter-column $\operatorname{spaces}^{23}$ (fig. 1). ${ }^{24}$ Only in seven cases are the notes written in straight lines with no geometric or vegetal shapes: fols. 97v, 119r, 130v, 201r, 240r, 248r and 257r. When the arrangement of the biblical text changes from three columns to two (especially in Psalms, Job and Proverbs ${ }^{25}$ ) or when there is a decora-

\footnotetext{
${ }^{22}$ In two cases (fols. 50v and 180v) the Masoretic notes are written in three lines with a stichography arrangement.

${ }^{23}$ Fol. 116v also contains a triangle placed in the outer margin and fol. $238 \mathrm{r}$ has one triangle on top of the three straight lines and another one under the last line and on top of one of the inter-column spaces.

${ }^{24}$ All the images of the article belong to BH Mss1 at the Biblioteca Histórica Marqués de Valdecilla. Reproduced with the permission of the Biblioteca Histórica Marqués de Valdecilla.

${ }^{25}$ Apart from fols. 248r, 257r, 257v and 258r.
} 
ted seder mark in one of the inter-column spaces, ${ }^{26}$ the Masoretic notes in figured pattern appear right on top of one of the inter-column spaces (fig. 2). ${ }^{27}$ In five cases (fols. 3r, 3v, 23r, 23v and 81r), the figured MM notes go into the inter-column space and occupy half of it (fig. 3 ).

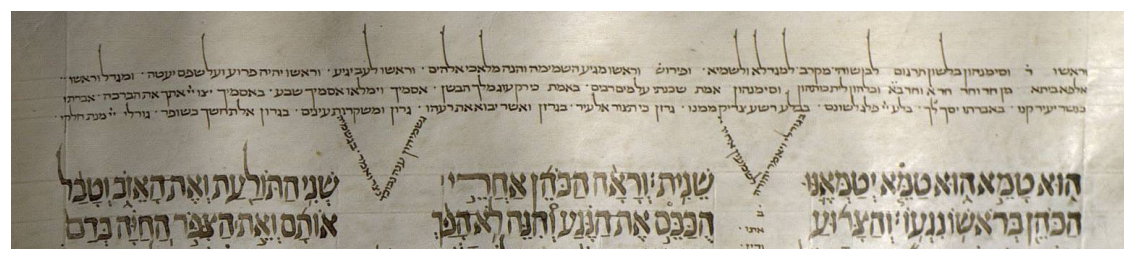

Figure 1. Fol. 41v

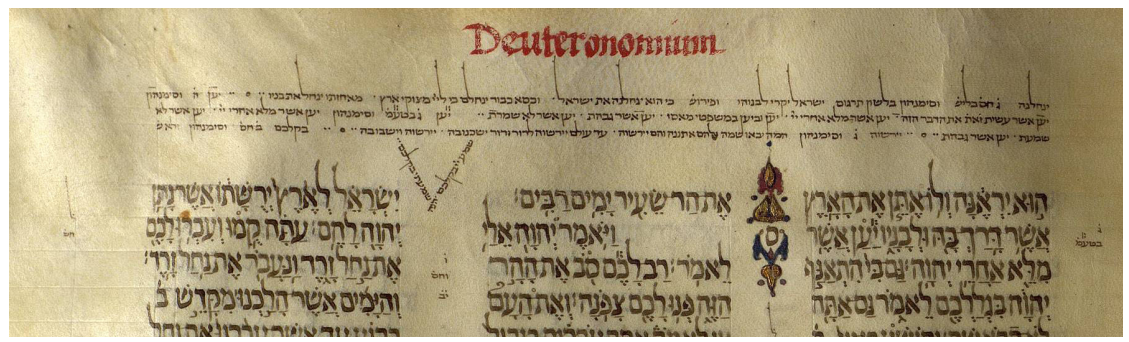

Figure 2. Fol. 66v

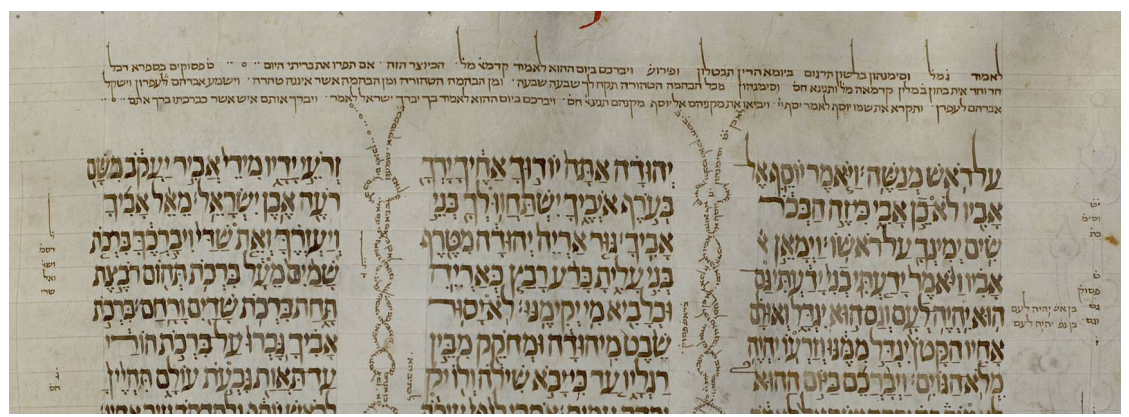

Figure 3. Fol. 23r

${ }^{26}$ Fols. 17v, 19v, 29r, 29v, 31r, 43r, 45v, 66v, 76r, 117r, 140r, 187v, 216r and 238r.

${ }^{27}$ There are also some cases in which the geometric design occupies just one of the inter-column spaces for no apparent reason: fols. 156v, 197v and 331r. 
The information written in figured patterns is usually part of a note that also has information written in non-figured patterns. Most of these notes start in the last straight line and continue in the patterns placed under that line; others start in the patterns placed under the last line and continue in the lower MM, usually written in non-figured patterns (i.e., fol. 224r).

The most common design is a single triangle. It is also possible to find double-lined triangles (fols. 3r, 3v, etc.) and some triangles with a line in the middle (e.g., fols. 31v, 51v, 69r, 229v, etc.). There are some exceptions in which semicircles are used (fols. 5r, 5v, 6r, 6v, 7r, 7v, 8r, $8 \mathrm{v}, 9 \mathrm{r}, 9 \mathrm{v}, 10 \mathrm{r}, 10 \mathrm{v}$ and $92 \mathrm{v}$ ) and once (fol. 25v) double-lined semicircles are employed. Moreover, the designs in the cases where the MM notes go into the inter-column spaces contain geometric and vegetal motifs (such as spade-shape leaves and full acanthus leaves).

\subsubsection{The lower MM}

The Masoretic notes placed at the bottom margin are generally written in four straight lines (four hundred and six times). To a lesser extent (two hundred and sixty-three times), they are written in four straight lines combined with figured patterns, mostly geometrical, placed under the fourth line. In nineteen cases the Masoretic notes in figured patterns are also placed on the first line and go into the inter-column spaces ${ }^{28}$ or go up around the sekum. ${ }^{29}$ Finally, there are two exceptional cases (fols. 3r, 3v) in which all the information in the lower MM is given in figured patterns. Each note is clearly differentiated from the following one by the sequence of two dots-circle-two dots.

The most common design is a repetition of the combination of doublelined semicircles with inverted triangles, which can appear tighter or longer depending on the content. But it is possible to distinguish up to eleven different patterns made up of simple and double-lined semicircles, circles and triangles and also some examples of stichography arrangements and vegetal layouts (figs. 4-11).

${ }^{28}$ Fols. 3r, 3v, 11r, 11v, 13r, 13v, 18r, 18v, 22v, 23r, 23v, 25r, 25v, 36r, 36v, 41r and $41 \mathrm{v}$.

${ }^{29}$ Fols. 159v and 240r. 


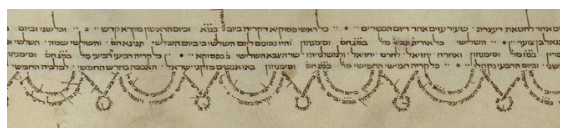

Figure 4. Fol. 52r

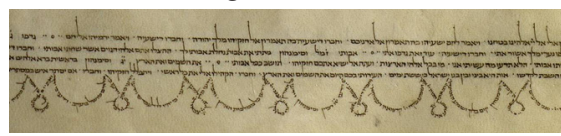

Figure 6. Fol. 156r

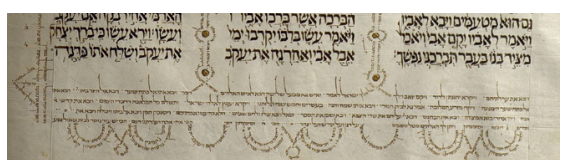

Figure 8. Fol. 13r

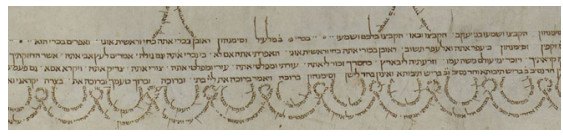

Figure 10. Fol. 23r

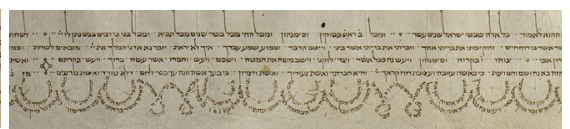

Figure 5. Fol. 5r

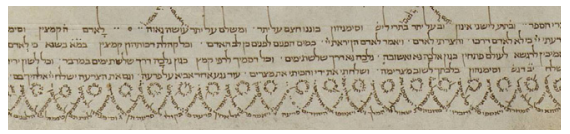

Figure 7. Fol. 25r

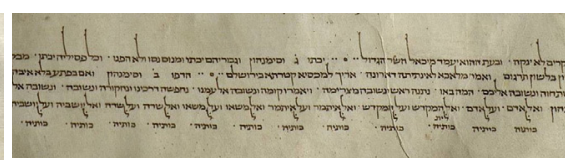

Figure 9. Fol. 180r

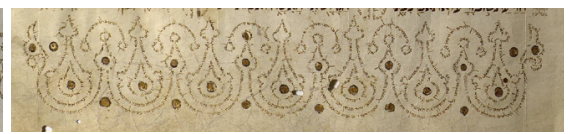

Figure 11. Fol. 3v

Moreover, the Masoretic notes placed in the lower MM usually continue in figured patterns into the outer margins of the page. The connection between the notes placed in both margins is usually represented graphically. The connection is also attested by the notes that begin in the lower $\mathrm{MM}$ - written in straight lines or in the figured patterns placed under the lines - and continue in figured patterns in the outer margins. Only in foure teen cases the notes of the lower MM are confined to the bottom margin. ${ }^{30}$

Taking into the account the size and place, the lower MM located in the outer margins can be classified into two subgroups that I call: a) small outer lower MM; and b) big outer lower MM. ${ }^{31}$ Both subgroups usually appear separately but appear together twenty-two times. ${ }^{32}$

${ }^{30}$ Fols. 5r, 8r, 21r, 34r, 41r, 45r, 47r, 75r, 89r, 100r, 105r, 156r, 197r and 321r.

${ }^{31}$ There is one more case of MM in figured patterns - a six pointed star inside a rosette - placed in the outer margin of fol. 5r. However, it cannot be classified in any of these groups due to its place: in the middle of the outer margin without a clear connection with either the upper MM or the lower MM. Moreover, one of the Masoretic notes identified in the design is on the word רשאי (Gen 8:5) located on the next folio, 5v.

${ }^{32}$ Fols. 3r, 6v, 7v, 8v, 9v, 16v, 17v, 18v, 22v, 23v, 35v, 36v, 65v, 79v, 85v, 91v, 95v, $97 \mathrm{v}, 106 \mathrm{v}, 130 \mathrm{v}, 140 \mathrm{v}$ and $224 \mathrm{v}$. 
a) Small outer lower MM

This usually fills the lower part of one of the outer margins. ${ }^{33}$ Except for eleven cases, ${ }^{34}$ it is found in all the manuscript folios.

The variety of patterns used to write the notes of this Masorah is huge: one hundred and fifty different designs, seventy-nine of them used just once. The designs range from the most simple - one or two parallel lines - to the most elaborate, in which several different elements (triangles, semicircles, lines) are combined (figs. 12-18). Most of these designs are geometric but there are also a few in vegetal layouts (fig. 19). The most frequent designs are a triangle upon a line (134 times) and one vertical line (98 times).

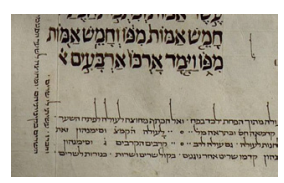

Figure 12. Fol. 201r

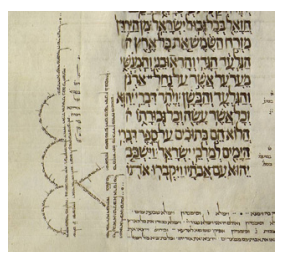

Figure 16. Fol. 151v

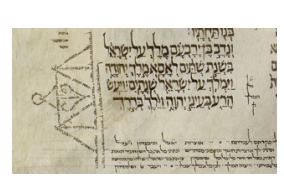

Figure 13. Fol. 141v

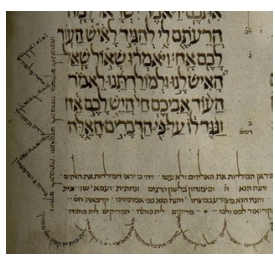

Figure 17. Fol. 20r

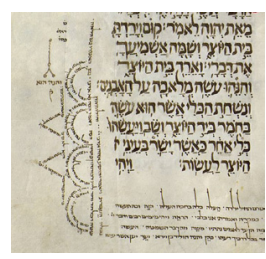

Figure 14. Fol. 167v

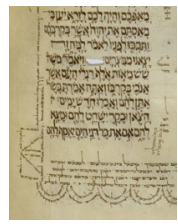

Figure 18. Fol. 54r

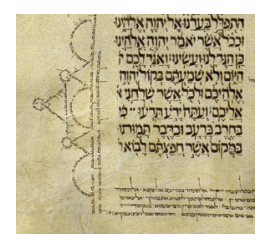

Figure 15. Fol. 178v

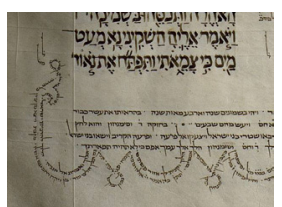

Figure 19. Fol. 97r

b) Big outer lower MM

The notes of this Masorah usually occupy nearly the entire length of the outer margin - the left margin on the verso and the right margin on the

${ }^{33}$ Some cases extend beyond half the folio: fols. $24 \mathrm{v}, 38 \mathrm{v}, 44 \mathrm{v}, 52 \mathrm{v}, 54 \mathrm{v}, 63 \mathrm{v}, 92 \mathrm{r}$, $191 \mathrm{v}, 198 \mathrm{v}, 200 \mathrm{v}, 201 \mathrm{v}, 202 \mathrm{v}, 205 \mathrm{v}, 213 \mathrm{v}, 214 \mathrm{v}, 274 \mathrm{v}, 287 \mathrm{v}, 293 \mathrm{v}, 306$ and 335v.

${ }^{34}$ Fols. 5r, 8r, 21r, 34r, 41r, 75r, 100r, 105r, 156r, 197r and 321r. 
recto - and almost the width of one text-column, except for some cases that are smaller. ${ }^{35}$ Moreover, two cases are found in the space that is usually occupied by the left text column (fols. $81 \mathrm{v}$ and $159 \mathrm{v}$ ).

Most of them are located in the Pentateuch and some in the Prophets in the outer margins of the following folios: 3r, 3v, 4v, 5r, 5v, 6r, 6v, 7r, $7 \mathrm{v}, 8 \mathrm{v}, 9 \mathrm{v}, 14 \mathrm{v}, 16 \mathrm{v}, 17 \mathrm{v}, 18 \mathrm{v}, 22 \mathrm{v}, 23 \mathrm{v}, 25 \mathrm{v}, 35 \mathrm{v}, 36 \mathrm{v}, 65 \mathrm{v}, 79 \mathrm{v}, 80 \mathrm{r}$, $80 \mathrm{v}, 81 \mathrm{v}, 85 \mathrm{v}, 91 \mathrm{v}, 95 \mathrm{v}, 97 \mathrm{v}, 106 \mathrm{v}, 130 \mathrm{v}, 140 \mathrm{v}, 145 \mathrm{v}, 159 \mathrm{v}, 168 \mathrm{v}, 224 \mathrm{v}$ and $232 \mathrm{v}$.

Apart from fol. $9 \mathrm{v},{ }^{36}$ the notes of this Masorah appear beside the MP notes, sharing the space. The MP notes are usually placed between the main text and the big outer lower MM notes, although they can also be placed: in the outer side of the big outer lower MM notes (fol. 22v), to both sides (fols. 16v and 79v), in the middle of the big outer lower MM notes (fol. 168v) or on the top (fol. 14v).

The most frequent motif is the so-called candelabra tree, ${ }^{37}$ of which there are eighteen in total $^{38}$ (figs. 20-37). The tree-shaped motifs are formed by a vertical series/pattern of three branches, one central branch and two others that protrude sideways and then upwards. The repetition of the pattern varies from one candelabra to another. Apart from fol. 16v (fig. 26), where this motif appears just once, it can be repeated two (fol. $8 \mathrm{v}$ ), three (fol. 17v), four (fols. $3 \mathrm{v}, 14 \mathrm{v}, 65 \mathrm{v}, 80 \mathrm{r}$ ), five (fols. $18 \mathrm{v}$ and $25 \mathrm{v}$ ),

${ }^{35}$ Fols. 5r, 6r, 35v, 79v, 85v, 91v, 130v and 145v.

36 There is only one reference to the differences between Ben Asher-Ben Naftali. The notes about these readings are written in a hand different from that of the masorah of the manuscript; cf. M. ${ }^{a}$ T. Ortega Monasterio, "Some Hillufim Ben Asher/Ben Naftali in the Manuscript M1," Sefarad 57:2 (1999) pp. 371-390: 378; M. a T. Ortega Monasterio and E. Fernández Tejero, "Distintas manos en la Masora Parva del Pentatueco del Códice M1" in Judaísmo hispano: estudios en memoria de José Luis Lacave Riaño, coord. por Elena Romero CAstelló (Madrid: CSIC, 2002) pp. 145-161: 147.

${ }^{37}$ According to the terminology and definition given by HALPERIN, Illuminating in Micrography, p. 15, n. 44: "candelabra tree is a term used to describe decorations that adorn the margins in the Iberian manuscripts. They generally resemble both a tree and a candelabra with three arms."

${ }^{38}$ Fols. 3r, 3v, 6r, 8v, 9v, 14v, 16v, 17v, 18v, 22v, 23v, 25v, 36v, 65v, 80r, 95v, 106v and $159 \mathrm{v}$. 
six (fol. 106v), seven (fols. 23v and 95v), eight (fol. 9v), ten (fols. 3r and $22 \mathrm{v}$ ), thirteen (fol. 36v) and up to sixteen times (fol. 6r).

The central branch is usually higher than the sideways branches, apart from two cases, fols. $3 \mathrm{v}$ and $18 \mathrm{v}$. Most of the candelabras have rounded branches, but there is also one case with straight branches (fol. 16v), one with a mixture of branches (fol. 95v), and another two with full acanthus or acanthus semi-leaves as branches (fols. $36 \mathrm{v}$ and $6 \mathrm{r})$.

The branches usually end in a spade-shape leaf - sometimes with one or more circles on top but also in a full acanthus leaf (fol. 23v), in an acanthus semi-leaf or in a mixture of some or all of them (fols. $3 \mathrm{r}, 9 \mathrm{v}$, etc.). These elements are also interspersed along the central branch and sometimes along the branches.

These candelabra trees are usually depicted with a base split into two acanthus semi-leaves but other elements for the base can also be found such as: a square with small circles at the corners and decorative coloured elements (fol. 3r); a circle with a six-pointed star inside in addition to a spade-shape leaf (fol. 9v); a hose-shape with some geometric elements inside (fol. $14 \mathrm{v}$ ); a double-lined circle with a lozenge and a small circle inside (fol. 18v); an inverted crown-shape (fol. 36v); a double-lined triangle with two acanthus semi-leaves plus an inverted triangle with two acanthus semi-leaves (fol. 80r). The terminating decoration placed at the top can be: one or two spade-shape leaves, a double semicircle with small circles, a semicircle, a full acanthus leaf, a full acanthus leaf with spade-shape leaf on top, two acanthus semi-leaves, two acanthus semi-leaves with a spade-shape leaf, three spade-shape leaves one on top of the other, or no decorating element (fol. 18v)

All these figures are different and their designs differ significantly from the design of the most well-known Catalan candelabra. ${ }^{3}$

${ }^{39}$ Kogman-Appel, Jewish Book Art, p. 60. 
THE IMAGE AT THE SERVICE OF THE TEXT: FIGURED MASORAH IN THE BIBLICAL HEBREW

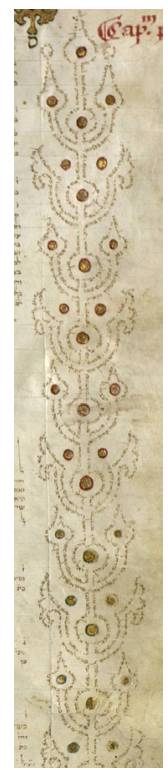

Figure 20.

Fol. $3 \mathrm{r}$

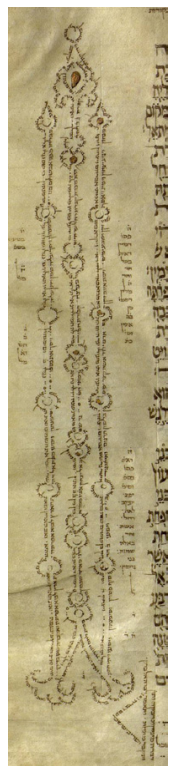

Figure 26. Fol. 16v

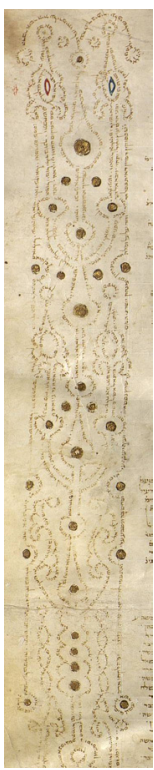

Figure 21 .

Fol. 3v

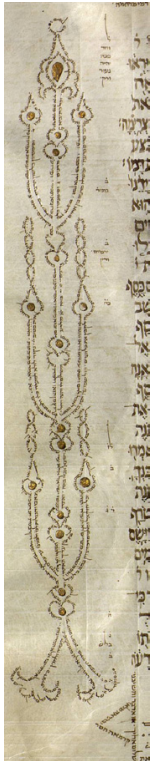

Figure 27.

Fol. 17v

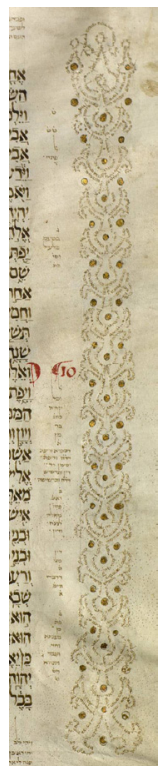

Figure 22.

Fol. 6r

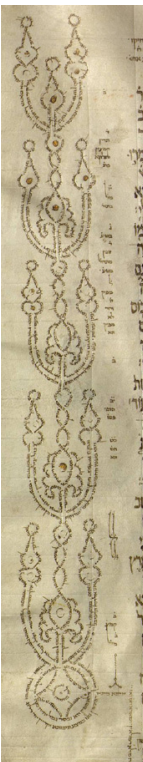

Figure 28. Fol. 18v

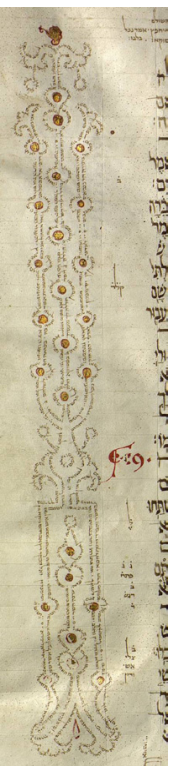

Figure 23.

Fol. 8v

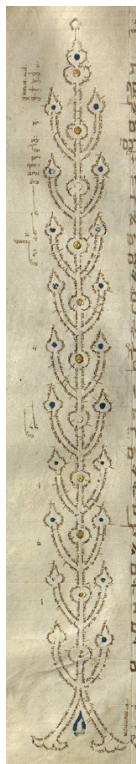

Figure 29.

Fol. 22v

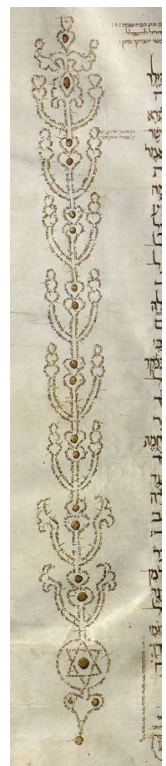

Figure 24

Fol. 9v

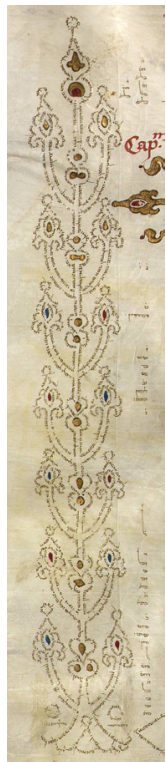

Figure 30 .

Fol. 23v

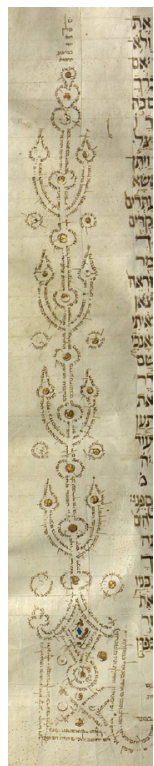

Figure 25.

Fol. 14v

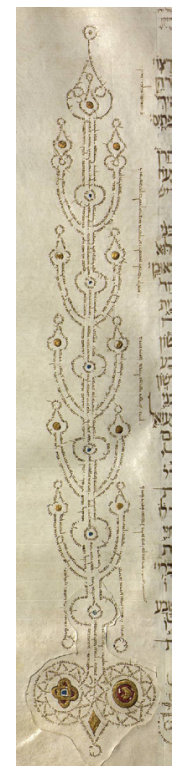

Figure 31.

Fol. 25v 


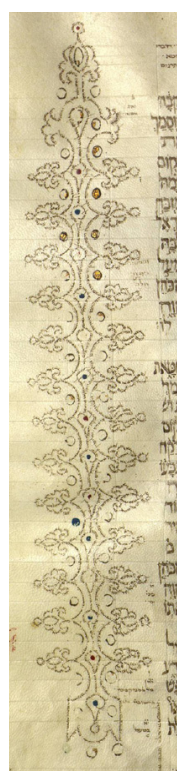

Figure 32.

Fol. 36v

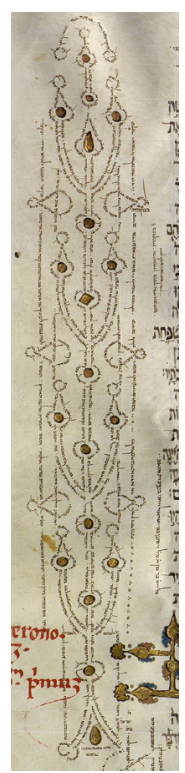

Figure 33 . Fol. 65v

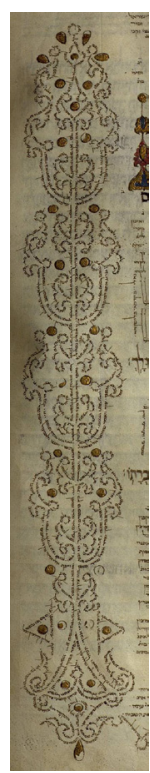

Figure 34 . Fol. 80r

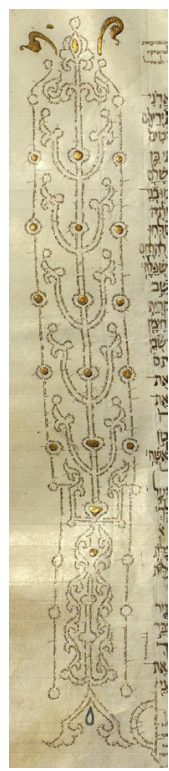

Figure 35. Fol. 95v

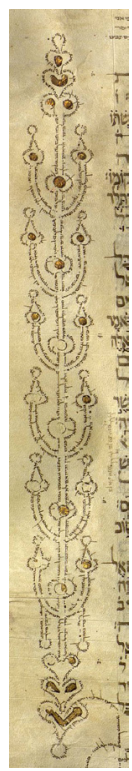

Figure 36 . Fol. 106y

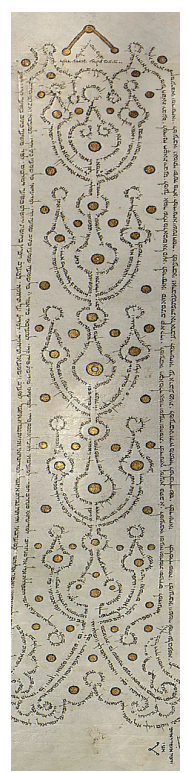

Figure 37.

Fol. 159v

A variation of the tree-shape motif is found three times (fols. 80v, $130 \mathrm{v}$ and $145 \mathrm{v}$ ). This variation consists of additional branches that protrude from the side branches in the opposite direction, downwards. They have rounded and straight branches that end in either an acanthus semi-leaf or a spade-shape leaf. The elements used for the top and the base are similar to those of the most common candelabra tree (fig. 38).

In addition to this pattern, interlaces with vegetal elements, such as full acanthus leaves, acanthus semi-leaves and spade-shape leaves can be found (fols. 79v, 85v and 91v; fig. 39). These elements are arranged vertically with a spade-shape leaf plus one circle or a full acanthus leaf on top and the base splits into two acanthus semi-leaves.

There are also interlaces of geometric and vegetal forms (fols. $4 \mathrm{v}, 5 \mathrm{v}$, $81 \mathrm{v}$ and 140v; fig. 40), very elaborate carpet designs (fols. 6v, 7r, 7v and 97v; fig. 41), and designs formed by geometric elements (fols. 168v, 224v and 232v; fig. 42). 


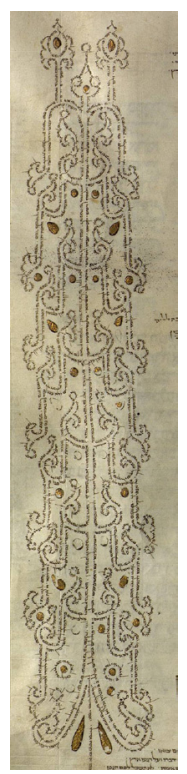

Figure 38. Fol. $80 \mathrm{v}$

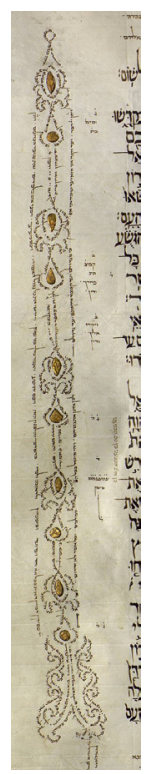

Figure 39 Fol. $85 \mathrm{v}$

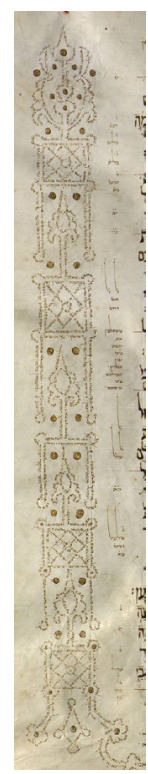

Figure 40. Fol. 5v

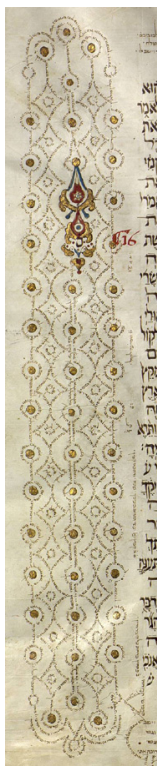

Figure 41 . Fol. 7v

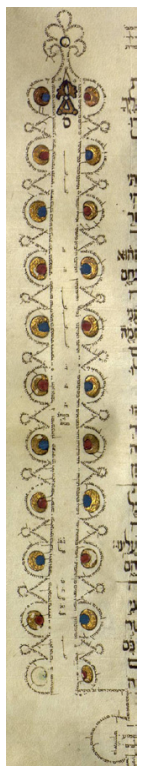

Figure 42 .

Fol. 168v

Apart from some exceptions (fols. 6v, 7v, 81v, 140v and 232v), the designs also incorporate small decorative circles that are usually gold and very rarely red or blue (fols. 22v, 25v and 36v). Other decorative coloured geometric elements are used, including a blue tear (fols. 3r, 3v, 23v and 95v), blue triangle (fols. 3r and 3v) and red triangle (fol. 3v). The decorated seder and parasha marks are integrated into the design three times: fols. $4 \mathrm{v}, 7 \mathrm{v}$ and $168 \mathrm{v}$.

\subsection{Sekum ${ }^{40}$}

Six of the summaries that appear at the end of each biblical book ${ }^{41}$ con- $^{-}$ tain part of the information written in figured patterns: fols. $23 \mathrm{v}, 48 \mathrm{r}, 95 \mathrm{v}$, $106 r, 132 \mathrm{r}$ and $265 \mathrm{v}$.

${ }^{40}$ I have differentiated this information from the Masoretic rubrics contained in the so-called "appendices" placed after several divisions of the Bible and with a common shape, i.e. blank folio, text in three columns, blank folio; cf. Martín-Contreras, "M1's Masoretic Appendices," pp. 65-81.

${ }^{41}$ Except for the books where the summary has been cut (Isaiah, Jonah, Nahum, Habakkuk, Ruth, Job, Lamentations, Nehemiah) and the book of the Chronicles (considered just one book by the Masorah). 
The geometric shape used is the triangle: alone (three times), with a line in the middle (once) and a sequence of two triangles (twice).

Except for fol. $265 \mathrm{v}$, the information is inserted into a decorated rectangular frame (fig. 43).

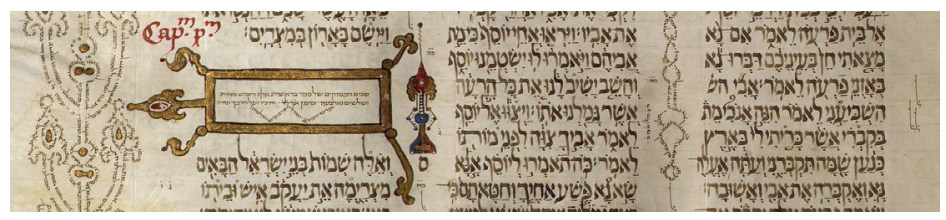

Figure 43. Fol. 23r

\section{CONTENT}

Manuscript M1 contains a correct and comprehensive Masorah. ${ }^{42}$ The information contained in the Masorah does not differ significantly from the data in the Masorah of the Tiberian manuscripts of high quality, in particular the Aleppo Codex (A) and the Leningrad Codex (L). The main difference between the Masoretic information in M1 and those of $\mathrm{A}$ and $\mathrm{L}$ is how the former is expressed. It is well known that Masoretic notes are characterized by being formulated in a short, concise way, and on many occasions elliptically. ${ }^{43}$ However, the Masoretic notes in M1 exhibit a tendency to be more explicit: ${ }^{44}$ the MP notes usually offer some information and not

${ }^{42}$ The information contained in all the Masoretic notes has been consulted in its entirety, both the published version (cf. footnotes 16 and 19) and the unpublished material. With the unpublished material, I did a direct reading of the Masoretic notes using a digitalized version of the manuscript. Due to the amount of material, the data presented here is not detailed; instead, the most important features are summarized.

${ }^{43}$ Cf. E. Martín-Contreras, "Masorah and Masoretic Interpretation" in The [Oxford] Encyclopedia of Biblical Interpretation, ed. STEven L. MCKenzie (2 vols.; Oxford University Press, 2013) vol. I, pp. 542-550.

ויאמר ${ }^{44}$ As can be seen in the comparison of the MM regarding the expression from Gen 1:3 found in M1 and L, cf. Fernández TeJero, Las masoras del libro del Génesis, pp. XIX-XX. Because of this, M1 has been used to help to decipher the obscure cases in the Masorah of L; cf. C. McCarthy, "A Comparative Study of the Masorah Magna and Parva of the Book of Deuteronomy as Attested in the Leningrad and Madrid M1 Manuscripts," in Sofer Mahir: Essays in Honour of Adrian Schenker Offered by Editors of Biblia Hebraica Quinta, eds. Y. A. P. Goldman, A. VAn Der KooIJ, R. D. Weis (Leiden-Boston: Brill, 2006) pp. 177-191. 
just a mere number, the simanim - i.e., "references" or "catchwords" - are formed by more than two words, ${ }^{45}$ there is less use of abbreviations in the MM notes, the MP notes usually use the formula' וסימ' כת 'their simanim are written') to indicate that there is a related MM note that gives the references for the complete list of occurrences, etc. This tendency is also seen in the amount of information included. For instance, the number of MM entries is usually higher in M1 than in the Tiberian manuscripts. This means that, at times, there are so many notes in the MM that they do not fit on the corresponding page and appear on the following page (for instance in the book of Genesis), ${ }^{46}$ or that the number of entries with MM notes that lack a corresponding MP note is higher than usual. Indeed, some words have two MP or MM notes with the same or different information. ${ }^{47}$

The content of the Masoretic notes written in figured patterns is similar to that given in the notes written in straight lines. ${ }^{48}$ In the MM notes, there is no distinction between the information given in the two formats: the lists of the collative type - known as Collative MM notes $-{ }^{49}$ predominate; alongside them are elaborative-type lists - the most common type in the MM notes of other manuscripts - which give the occurrences of a single word or combination of words. The same occurs with the sekum, where the information given in the two formats is the same: the number of pesaqîm, the parasiyyôt and the middle verse.

In the case of the information contained in the MP notes, small differences can be detected. Despite the similarity of the contents in the notes written in both formats, some kinds of contents are predominant in the notes written in figured patterns. One example is the notes that give not only informa-

${ }^{45}$ YeIVIN, Introduction, p. 75: "In the earlier MSS these simanim are short - usually one word only."

${ }^{46}$ Although the Masoretic notes are usually written on the same page as the corresponding lemma in the manuscript. Those words are usually marked in the main biblical text with a circellus.

47 The existence of two MP notes for one word is sometimes indicated by two circelli (fol. 139v).

48 YeIVIN, Introduction, pp. 74-80.

${ }^{49}$ Following Yeivin's categories: words, phrases or verses which are different, but which share some common characteristic; or words, phrases or verses which are the same except for some characteristic; cf. YeIvIN, Introduction, pp. 78-80. 
tion - the number of cases - but also references to the individual passages in which the words in question occur. The most numerous - and also the most common in the Masoretic codes $-{ }^{50}$ are MP doublet notes with attached catchwords referring to the other occurrence. There are also MP notes that mention and provide references to three (fols. 27v, 62r, 161v, 249r), four (fols. 57v, 59v, 65v, 174r), five (fols. 3v, 13r, 130r, 131r, 232v), six (fol. 136r) and up to nine (fol. 167r) cases. In the other codices, the Masoretic notes giving the references are usually found in the MM and not the MP.

Likewise, the notes similar in content to the aforementioned Collative MM notes are predominantly collated in the MP notes written in figured patterns. The difference from the MM notes is that the MP notes only include the heading of the list, without providing the references. This type includes notes that describe what the reading proposed by the Qere consists of and the number of cases that share the same Qere reading (fols. $111 \mathrm{r}, 116 \mathrm{v}, 137 \mathrm{v}$, etc.), usually located next to a Qere indication.

All of these characteristics regarding the content of the MP notes in figured patterns confirm the tendency in M1 to present the Masoretic information more explicitly.

\section{ConClusions}

As we have seen, almost every folio of ms. M1 has Masoretic notes written in figured patterns. The notes can be found in any of the margins of the folio - inter-column spaces, upper, bottom and outer margins - but it is especially common in the upper margin (just 7 cases without any figured Masorah) and the lower outer margin (just 11 cases without it). The location of the Masoretic notes in figured patterns - especially those placed in the lower MM and the big outer lower MM - are sometimes related to the beginnings and endings of the biblical books, important passages in the text (the Song of Moshe, the Song of Deborah and David's Song of Praise) or to the material division of the book, ${ }^{51}$ but at other points

${ }^{50}$ Cf. D. Marcus, "Double Catchwords in the Leningrad Codex," TC 12 (2007) (http://rosetta.reltech.org/TC/v12/Marcus2007.pdf).

${ }^{51}$ HalPerin, "Decorated Masorah on the Openings," p. 346. 
they are not (e.g. the book of Genesis). The notes placed in the small outer lower MM, upper MM and MP have no any relation at all.

Quite often, the information about a word appears written in the two formats, one part of the note written in figured patterns and the other not. With the MM notes, in addition to the mixed format, notes appear whose information is divided and fills different spaces. For example, one part of the note appears in the upper MM and the other in the lower MM, or one part is in the lower MM and the other in the big or small lower MM.

The forms of the figured Masorah are mainly simple geometric shapes, such as triangles, semicircles, zigzags, circles or a combination of them. Vegg etal motifs and, exceptionally, other forms (e.g., a six-pointed star, a house shape, etc.) also appear. The thirty-seven cases of the big outer lower MM are an exception in the context of the manuscript. Their designs, elaboration and complexity contrast with the simplicity of the other types. One of the most striking characteristics of these cases is that none of the designs are identical. In this respect, the great variety of designs employed in the cases of the small outer lower MM is also noteworthy. Thus, it is in the outer margins where the form of writing the Masorah most stands out.

In terms of content, the Masoretic information contained in the figured Masorah is accurate, explicit and similar to that of the Masoretic notes that are not written in figured patterns. With a few exceptions, the notes include textual information on words or expressions in the biblical text written on that folio. The main characteristic of the M1 Masorah is how the information is expressed or transmitted, with a tendency to give the most information possible. This tendency is, in my view, key when it comes to understanding and explaining the shape adopted by the Masorah in this manuscript.

The change in the usual way of expressing the Masoretic notes, from a high degree of conciseness, even ellipsis, to explicitness, generated a large amount of information. It was not possible to record the entire amount in the spaces traditionally set aside for that purpose. The upper and bottom margins allocated for the MM could no longer accommodate all the information. It was necessary to take over more space, but the only space available was that already earmarked for the MP notes, which was not much if the information was to be written in straight lines as usual. 
In my view, these two "obstacles" - the lack of space and the need to share it - brought about the change in the form. Writing the Masorah in figured patterns solved both problems. On the one hand, the design pattern serves as a visual separation between the MP notes and the MM ones. ${ }^{52}$ On the other hand, the arrangement of the text in these patterns makes it possible to include a larger amount of information.

The fact that none of the designs in the big outer lower MM and almost none of those in the small outer lower MM are the same confirms the close connection between the shape and the amount of information. The shapes are determined by the Masoretic information the scribe had to copy in each folio. For instance, the series of geometric elements (triangles, semicircles, zigzags, circles etc.) are made up of a greater or lesser number of units. In the case of the candelabra tree, the repetition of the pattern of three branches, depend on the amount of information that must be incorporated in that folio.

Therefore, one of the main purposes behind writing the Masorah in figured patterns in manuscript M1 is a practical one. The Masorah adapts its usual shape in order to record all the information in the available space, but without losing its original function (of providing textual information about some of the words in the biblical text written on that page), place (the spaces between the columns and the top and bottom of the page) and size (always a very small letter). However, it is also true that the result is decorative as well and there is an aesthetic intentionality, as seen in the use of gold circles and other coloured elements and the use of lines to complete the design.

In short, biblical Hebrew manuscript BH MSS1 is exceptional in the context of 13th-century Hebrew Bibles on the Iberian Peninsula not only due to the high number of Masoretic notes in figured patterns and the profusion of designs used, but also because of the content and way of expressing it.

Recibido: 05/11/2015

Aceptado: 01/04/2016

${ }^{52}$ The MP notes are usually written in horizontal lines. In only a few cases do the figured MM coexists with the figured MP (fols. 4v, 7r, 25v, 54v, etc.) and their design is a vertical line with the separation made clear. 